\title{
Factors Associated with Mortality in Maintenance Hemodialysis Patients: A Single-Center Data from East Anatolian Region of Turkey Hemodiyaliz Hastalarında Mortalite ile Illişkili Faktörler: Türkiye'nin Doğu Anadolu Bölgesinden Tek Merkezli Bir Veri
}

\author{
(1) Şiyar Erdoğmuş1 ${ }^{1}$, (D) Fatma Kaymakamtorunları² \\ ${ }^{1}$ Başkent University Faculty of Medicine, Department of Nephrology, Ankara, Turkey \\ ${ }^{2}$ Ankara University Faculty of Medicine, Department of Biostatistics, Ankara, Turkey
}

\section{Abstract}

Objectives: Patients on maintenance hemodialysis have a high mortality risk compared to the general population. There have been reported many risk factors that affect the mortality of these patients. The aim of this study was to evaluate the clinical and laboratory characteristics of these patients and to identify risk factors that contributed to their mortality.

Materials and Methods: This study was a retrospective observational cohort study conducted between January 2018 and January 2020. At the start of the study, all of patients were clinically evaluated, and data regarding demographic, clinic, and laboratory characteristics were collected. At the end of 2-year follow-up period, the patients were separated into two groups according to their survival status. Data were analyzed between the survival and death groups. Logistic regression analysis was used to evaluate risk factors associated with mortality.

Results: A total of 74 patients ( $53 \%$ females and $47 \%$ males) were included in the analysis. The mean age of the study population was $53.04 \pm 14.61$ years. At the end of 2-year follow-up period, 21 (28.4) patients died, and four (5.4) received a kidney transplant. The leading cause of death was cardiovascular events (52.2\%), followed by infections (43\%). Compared with the survival group, the death group patients had higher rate of comorbid conditions, older age, required higher erythropoiesis stimulating agent doses, lower levels of serum creatinine and albumin, and higher levels of C-reactive protein (CRP). The presence of diabetes mellitus, cerebrovascular disease, and high CRP levels are independent risk factors for mortality.

Conclusion: An early and careful evaluation is essential in the follow-up of the patients in order to improve survival in this group of patients. Largescale multicenter studies are needed to better determine the causes of increased risk of mortality in maintenance hemodialysis patients.

Key Words: Mortality, Risk Factors, Hemodialysis

\section{Özet}

Amaç: Hemodiyaliz hastaları genel popülasyona göre yüksek mortalite riskine sahiptir. Bu hastaların mortalitesini etkileyen birçok risk faktörü bildirilmiştir. Bu çalışmanın amacı, bu hastaların klinik ve laboratuvar özelliklerini değerlendirmek ve mortalitelerine katkıda bulunan risk faktörlerini tanımlamaktır.

Gereç ve Yöntem: Çalışma Ocak 2018 ile Ocak 2020 arasında yapılan retrospektif gözlemsel bir kohort çalışmasıdır. Çalışmanın başlangıcında tüm hastalar klinik olarak değerlendirildi ve demografik, klinik ve laboratuvar özellikleri ile ilgili veriler toplandı. İki yılık takip süresinin sonunda hastalar sağkalım durumuna göre iki gruba ayrıldı. Hayatta kalan ve ölen gruplar arasında veriler analiz edildi. Mortalite ile ilişkili risk faktörlerini değerlendirmek için lojistik regresyon analizi kullanıldı.

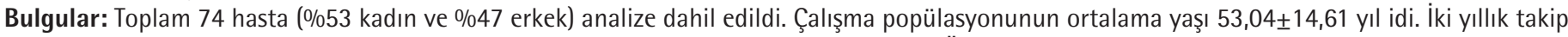
süresinin sonunda $21(28,4)$ hasta öldü ve dört $(5,4)$ hastaya böbrek nakli uygulandı. Önde gelen ölüm nedeni kardiyovasküler olaylar $(\% 52,2)$, ardından enfeksiyonlar (\%43) idi. Hayatta kalan hasta grubuyla karşılaştırıldığında, ölen hasta grubunda daha yüksek komorbid durumlar, daha ileri yaş, daha yüksek eritropoezi uyarıcı ajan dozları, daha düşük serum kreatinin ve albümin seviyeleri ve daha yüksek C-reaktif protein (CRP) seviyeleri gözlendi. Diabetes mellitus, serebrovasküler hastalık ve yüksek CRP seviyeleri mortalite için bağımsız risk faktörleri idi.

Address for Correspondence/Yazışma Adresi: Dr. Şiyar Erdoğmuş, MD,

Baskent University Faculty of Medicine, Department of Nephrology, Ankara, Turkey

Phone: +90 3122030325 E-mail: siyarerdogmus@gmail.com ORCID: orcid.org/0000-0003-3787-6754

Received/Geliş Tarihi: 08.07.2020 Accepted/Kabul Tarihi: 20.07.2020

๑Copyright 2020 Ankara University Faculty of Medicine

Journal of Ankara University Faculty of Medicine is published by Galenos Publishing House.

All content are under CC BY-NC-ND license. 
Sonuç: Bu hasta grubunda sağkalımı artırmak için hastaların takibinde erken ve dikkatli bir değerlendirme şarttır. Hemodiyaliz hastalarında mortalite riskinin artmasının nedenlerini daha iyi belirlemek için büyük ölçekli çok merkezli çalışmalara ihtiyaç vardır.

Anahtar Kelimeler: Mortalite, Risk Faktörleri, Hemodiyaliz

\section{Introduction}

The mortality rate in maintenance hemodialysis (MHD) patients remains high, despite the technical and medical improvements in the last years $(1,2)$. MHD patients have a high rate of mortality than that of the general population. Therefore, it is important to identify risk factors underlying mortality on MHD patients (3). Cardiovascular disease is very common in MHD patients and is the leading cause of death in these patients. However, non-cardiovascular causes of death are increased to the same extent as cardiovascular mortality on MHD patients $(4,5)$.

The increased risks of cardiovascular morbidity and mortality in MHD patients is related to an increased prevalence of traditional cardiovascular risk factors, including advanced age, diabetes mellitus (DM), hypertension (HT), obesity, smoking, and dyslipidemia $(6,7)$. In addition, the presence of multiple comorbid conditions is an increasingly common problem in MHD patients and is associated with worse cardiovascular outcomes (8). Systemic inflammation and malnutrition also play an important role, and are poor prognostic factors identified for incresed mortality $(9,10)$. MHD patients using central venous catheter (CVC) have been associated with an enhanced inflammatory state (11). Markers of nutritional status, such as serum albumin, serum creatinine, body mass index (BMI), and serum lipids are related to mortality, as are inflammatory markers such as C-reactive protein (CRP) and interleukin-6 $(12,13)$. Disorders of mineral metabolism have also been defined as risk factors contributing to mortality in hemodialysis patients, especially hyperphosphatemia, hyperparathyroidism, and an elevated calcium phosphorous product (14). Although the importance of non-cardivascular causes of death has been highlighted in MHD patients, it has been underestimated in clinical practice. In this context, the aim of the present study was to evaluate the risk factors associated with mortality in a cohort of patients on MHD.

\section{Materials and Methods}

\section{Patients and Study Design}

This was a retrospective observational cohort study conducted between January 2018 and January 2020 at the hemodialysis unit at Van Training and Research Hospital of University of Health Sciences in the city of Van, Turkey. We included 80 MHD patients in our study. Patients on hemodialysis therapy for less than 3 months, presence of autoimmune disease, malignancy, and acute or chronic infection, were excluded from the study. Six patients were excluded because of did not meet the criteria, two of them had hemodialysis therapy for less than 3 months, three had malignancies, and one had autoimmune disease.

At the start of the study, all of patients were clinically evaluated, and data regarding baseline demographic, clinic and laboratory parameters were obtained from the hospital database. Demographic and clinical parameters such as age, gender, BMI, smoking status, etiology of primary kidney disease, comorbidities, types of vascular access, hemodialysis frequency and duration, dialysis vintage, and medical prescriptions were collected. The total doses of erythropoietin used in the last year was recorded. In terms of common standardization, the doses of darbepoetin were indicated and per week of kilogram doses calculated. DM was defined based on the criteria of the American Diabetes Association or the use of medications such as oral hypoglycemic agents and/or insulin (15). HT was defined as a systolic blood pressure of at least $140 \mathrm{mmHg}$ and a diastolic blood pressure of at least $90 \mathrm{mmHg}$ and/or previously diagnosed HT and/or the use of antihypertensive medication (16). Patients with total serum cholesterol levels greater than or equal to $200 \mathrm{mg} / \mathrm{dL}$ or low-density lipoprotein (LDL) cholesterol above $100 \mathrm{mg} / \mathrm{dL}$ and triglycerides greater than $150 \mathrm{mg} / \mathrm{dL}$ or patients who were taking lipid-lowering drugs were considered dyslipidemia $(17,18)$. Patients with a history of myocardial infarction, angioplasty or myocardial revascularization were considered to have coronary artery disease (CAD). Those patients with a history of stroke or transient ischemic attack or those who had undergone carotid endarterectomy were defined as having cerebrovascular disease (CVD). Patients with a history of claudication, ulceration or amputation due to ischemia of the limbs or those who underwent peripheral revascularization were defined with peripheral arterial disease (PAD). When the medical records documented presence of signs and symptoms compatible with heart failure, and/or echocardiography findings support to heart failure, patients were diagnosed with heart failure. Those patients taking antiarrhythmic medications, or electrocardiogram changes of rhythm and rate, were defined as having cardiac arrhythmia.

\section{Biochemical Parameters}

Routine laboratory investigations of all patients were performed every month before hemodialysis session and recorded monthly. Averages of the biochemical parameters of the last year were used for analysis. Serum levels of hemoglobin, iron, iron binding capacity, ferritin, total cholesterol, triglycerides, LDL cholesterol, HDL cholesterol, creatinine, glucose, sodium, 
potassium, uric acid, calcium, phosphorus, parathyroid hormone, calcium phosphorous product, albumin, CRP, glycated hemoglobin $(\mathrm{HbA} 1 \mathrm{c})$, single pool $\mathrm{Kt} / \mathrm{N}$, and urea reduction ratio (URR) were determined using routine laboratory techniques.

\section{Follow-up and Outcomes}

At the end of 2 years follow-up period, the cases of death, kidney transplant, and transfer to peritoneal dialysis were recorded. Causes of death were determined as cardivascular events, infections, and gastrointestinal bleeding. Based on survival status, the patients were divided into two groups: group I (the survival group) and group II (the death group). Patients who were received a kidney transplant, or for any reason transferred to peritoneal dialysis were excluded in the survival group. Patient characteristics and the risk factors of mortality were compared among two groups.

\section{Statistical Analysis}

Data were analyzed with Statistical Package of Social Science (SPSS Inc., Chicago, IL, USA) software version 11.5 for Windows. Tests for normality of distribution for continuous variables were performed using the Kolmogorov-Smirnov test. Data were expressed as mean \pm standard deviation or median (interquartile range) for continuous variables according to their distribution and as number or percentages for categorical variables. The difference between the two groups was determined by independent t-test for numerical variables with normal distribution and by Mann-Whitney $\mathrm{U}$ test for numerical variables without normal distribution. Relationships between categorical variables were also determined by Pearson chisquare and Fischer's exact test. Relationships between numerical variables were examined with Pearson's correlation coefficient. Univariate logistic regression analysis was performed for all possible risk factors. In univariate analysis, variables with $p<0.25$ were accepted as candidate variables along with all known variables of clinical significance for the multivariate model. Variable selection for multiple models was made by Backward likelihood ratio method. Odds ratio and 95\% confidence interval were calculated for each independent variable. The value of $p<0.05$ was considered statistically significant.

\section{Results}

\section{Patients Characteristics}

A total of 74 patients (53\% females and $47 \%$ males) were included to analysis. All patients were under hemodialysis therapy three times peer week for 3-5 hours and the median dialysis vintage was 49 (3-324) months. The mean age of the study population was $53.04 \pm 14.61$ years. Seventeen percent of the patients were classified as underweight, while 19\% overweight and $11 \%$ obese. The etiologies of primary kidney disease were as follow: 19 (25.7) had diabetic kidney disease, four (5.4) had hypertensive kidney disease, eight (10.8) had glomerulonephritis, two (2.7) had polycystic kidney disease, two (2.7) had secondary amyloidosis, three (4.1) had reflux nephropathy, seven (9.5) had obstructive uropathy/nephrolithiasis, and 29 (39.2) had uncertain etiology. The majority of the patients $(82.4 \%)$ had HT. Additionally, 28.4\% had DM, 45.9\% dyslipidemia, 25.7\% CAD, 9.5\% CVD, 6.8\% PAD, 5.4\% cardiac arrhythmia, and 2.7\% heart failure. The prevalence of arteriovenous fistula usage was 83.8\% in MHD patients. Eighty-eight percent of total patients were received erythropoiesis stimulating agents (ESA) and half of the patients were using darbepoetin The mean hemoglobin level of was $10.64 \pm 0.74 \mathrm{~g} / \mathrm{dL}$. The prevalence of mortality was $28.4 \%$ within 2 years, while annual rate of mortality was approximately $15 \%$. The baseline characteristics of the study patients are presented in Table 1 and Table 2.

\section{Follow-up and Comparison of Two Groups}

At the end of 2 years follow-up period, 21 (28.4) patients had died, and four (5.4) had received a kidney transplant. The leading cause of death was cardiovascular events (52.2\%), followed by infections (43\%), and gastrointestinal bleeding $(4.8 \%)$. The mean age of the patients that died during the study period were significantly higher than that the survival patients $(59.66 \pm 11.89$ vs $51.71 \pm 14.48 ; p=0.030)$. Compared with the survival group, the death group patients had higher rate of comorbid conditions such as DM, HT, CAD, CVD, and $P A D$. However, statistically significant differences were found for HT and CVD between two goups ( $p=0.027$ vs $p=0.022$, respectively). There were no statistically significant differences between two groups in most clinical parameters such as gender, BMI, etiology of primary kidney disease, ultrafiltration volume, type of vascular access, viral serology, ESA usage, and smoking status. The median hemoglobin levels were not significantly different among the groups ( $10.4 \mathrm{~g} / \mathrm{dL}$ vs $10.6 \mathrm{~g} / \mathrm{dL} ; \mathrm{p}=0.095)$. In contrast, in the death group patients required significantly higher ESA doses than in the survival groups $(0.56 \pm 0.13 \mu \mathrm{g} / \mathrm{kg} /$ week vs $0.46 \pm 0.15 \mu \mathrm{g} / \mathrm{kg} /$ week; $p=0.014)$. The death group had lower median dialysis vintage than that the survival group, but not reaching statistically significance ( 32 months vs 54 months, $p=0.057)$. The death group patients had significantly lower levels of serum creatinine $(p=0.005)$ and albumin $(p=0.012)$, but higher levels of CRP $(p=0.026)$. The characteristics and comparisons of two groups are presented in Table 3.

To identify potential risk factors for mortality, we conducted logistic regression analysis. On univariate analysis, age $(\geq 65$ years), presence of CVD, levels of serum albumin lower than $3.5 \mathrm{~g} / \mathrm{dL}$, and elevated CRP levels were found associated with mortality. On multivariate analysis, the presence of DM [odds ratio $(\mathrm{OR})=3.583,95 \%$ confidence interval $(\mathrm{Cl})$ : 1.003-12.808, $\mathrm{p}=0.05], \mathrm{CVD}(\mathrm{OR}=8.217,95 \% \mathrm{Cl}: 1.263-53.442, \mathrm{p}=0.027)$, and 


\begin{tabular}{|c|c|}
\hline Parameters & All pateints $(n=74)$ \\
\hline Age (years) (mean \pm SD) & $53.04 \pm 14.61$ \\
\hline Gender (n) (female/male) & $39 / 35$ \\
\hline BMI $\left(\mathrm{kg} / \mathrm{m}^{2}\right)$ median (min, max) & $22.69(16.53-36.45)$ \\
\hline \multicolumn{2}{|l|}{ Primary kidney diseases, n (\%) } \\
\hline Diabetic kidney disease & $19(25.7)$ \\
\hline Hypertensive kidney disease & $4(5.4)$ \\
\hline Glomerulonephritis & $8(10.8)$ \\
\hline Polycystic kidney disease & $2(2.7)$ \\
\hline Amyloidosis & $2(2.7)$ \\
\hline Vesicoureteral reflux/pyelonephritis & $3(4.1)$ \\
\hline Urinary stone disease/obstructive uropathy & $7(9.5)$ \\
\hline Unknown & $29(39.2)$ \\
\hline \multicolumn{2}{|l|}{ Comorbidities, n (\%) } \\
\hline Diabetes mellitus & $21(28.4)$ \\
\hline Hypertension & $61(82.4)$ \\
\hline Dyslipidemia & $34(45.9)$ \\
\hline Coronary artery disease & $19(25.7)$ \\
\hline Cerebrovascular disease & $7(9.5)$ \\
\hline Peripheral vascular disease & $5(6.8)$ \\
\hline Arrhythmia & $4(5.4)$ \\
\hline Heart failure & $2(2.7)$ \\
\hline Dialysis vintage (months) median (min, max) & $49(3-324)$ \\
\hline \multicolumn{2}{|l|}{ Types of vascular access $n(\%)$} \\
\hline CVC & $12(16.2)$ \\
\hline AVF & $62(83.8)$ \\
\hline Ultrafiltration volume (L/week) (mean \pm SD) & $3.08 \pm 0.66$ \\
\hline $\mathrm{HBsAG}+\mathrm{n}(\%)$ & $3(4.1)$ \\
\hline Anti-HCV + n (\%) & $8(10.8)$ \\
\hline Smoking status + n (\%) & $18(24.3)$ \\
\hline $\mathrm{ESA}+\mathrm{n}(\%)$ & $65(87.8)$ \\
\hline Darbepoetin doses $(\mu \mathrm{g} / \mathrm{kg} /$ week) $($ mean $\pm \mathrm{SD})$ & $0.48 \pm 0.16$ \\
\hline
\end{tabular}

BMI: Body mass index, CVC: Central venous catheter, AVF: Arteriovenous fistula, ESA: Erythropoiesis stimulating agents, HBsAG: Hepatitis B surface antigen, HCV: Hepatitis $C$ virus, SD: Standard deviation, min: Minimum, max: Maximum, n: Number

elevated CRP levels (OR=4.340,95\% Cl: 1.306-14.416, $p=0.017$ ) were independent risk factors for mortality. Factors associated with mortality are presented in Table 4.

\section{Discussion}

In this study, we retrospectively examined 74 patients on MHD in order to identify parameters that could be associated with mortality. During the follow-up period, 21 patients died and four patients received a kidney transplant. The annual rate of mortality was $15 \%$. The causes of death were cardiovascular
Table 2: The baseline laboratory characteristics of the study patients

\begin{tabular}{|c|c|}
\hline Parameters & All patients $(n=74)$ \\
\hline Hemoglobin (g/dL) median (min, max) & $10.6(9-13.1)$ \\
\hline Iron $(\mu \mathrm{g} / \mathrm{dL})($ mean $\pm \mathrm{SD})$ & $70.38 \pm 21.38$ \\
\hline Iron binding capacity $(\mu \mathrm{g} / \mathrm{dL})($ mean $\pm \mathrm{SD})$ & $135.02 \pm 29.47$ \\
\hline Ferritin $(\mathrm{ng} / \mathrm{mL})($ mean $\pm \mathrm{SD})$ & $1071.04 \pm 470.62$ \\
\hline Total cholesterol $(\mathrm{mg} / \mathrm{dL})($ mean $\pm \mathrm{SD})$ & $151.01 \pm 31.72$ \\
\hline HDL cholesterol (mg/dL) median (min, max) & $34(20-60)$ \\
\hline LDL cholesterol (mg/dL) (mean \pm SD) & $78.28 \pm 23.89$ \\
\hline Triglycerides (mg/dL) median (min, max) & $158(65-447)$ \\
\hline Creatinine $(\mathrm{mg} / \mathrm{dL})($ mean $\pm \mathrm{SD})$ & $8.16 \pm 1.73$ \\
\hline URR (\%) median (min, max) & $72(54-81)$ \\
\hline $\mathrm{Kt} / \mathrm{V}($ mean $\pm \mathrm{SD})$ & $1.53 \pm 0.23$ \\
\hline Glucose (mg/dL) median (min, max) & $86.5(68-223)$ \\
\hline Sodium (mmol/L) median (min, max) & $138(135-141)$ \\
\hline Potassium (mmol/L) (mean $\pm \mathrm{SD})$ & $5.38 \pm 0.53$ \\
\hline Uric acid (mg/dL) (mean \pm SD) & $6.61 \pm 0.77$ \\
\hline Calcium (mg/dL) median (min, max) & $8.3(6.7-9.8)$ \\
\hline Phosphorus (mg/dL) (mean \pm SD) & $4.75 \pm 0.92$ \\
\hline $\begin{array}{l}\text { Calcium phosphorus product median (min, } \\
\operatorname{max)}\end{array}$ & $37.86(22.96-73.5)$ \\
\hline Albumin (g/dL) median (min, max) & $3.9(3-4.5)$ \\
\hline $\begin{array}{l}\text { Parathyroid hormone }(\mathrm{pg} / \mathrm{mL}) \text { median }(\min \text {, } \\
\text { max) }\end{array}$ & $365(12-2470)$ \\
\hline CRP (mg/dL) median (min, max) & $0.69(0.13-6)$ \\
\hline HBA1C (\%) median (min, max) & $5.2(4-8.7)$ \\
\hline \multicolumn{2}{|c|}{$\begin{array}{l}\text { HDL: High-density lipoprotein, LDL: Low-density lipoprotein, URR: Urea reduction } \\
\text { ratio, CRP: C-reactive protein, HBA1C: glycated hemoglobin, SD: Standard deviation } \\
\text { min: Minimum, max: Maximum, n: Number K: Dialyzer clearance of urea, t: Dialysis } \\
\text { time, V: Volume of distribution of urea }\end{array}$} \\
\hline
\end{tabular}

events for 11 patients, infections for nine, and gastrointestinal bleeding for one. Patients who died were older, had DM, HT, $C A D, C V D$ and $P A D$, and required higher ESA doses to achieve the target hemoglobin levels. In addition, the death group patients had lower levels of serum creatinine and albumin, while had higher levels of CRP. The presence of DM, CVD, and elevated CRP levels seem to be independent risk factors for mortality in MHD patients.

In spite of the considerable advances in the public health, MHD patients have high mortality rates. Almost half of the patients die due to cardiovascular disease. The high risk of cardiovascular mortality is associated with a high prevalence of known traditional cardiovascular risk factors. In addition, many MHD patients are of older age and have multiple comorbid conditions, as well as dysfunction of the immune system (3). Non-cardiovascular mortality is also increased on MHD patients, but the importance of non-cardiovascular mortality is often overlooked (19). de Jager et al. (4) analyzed data from the 


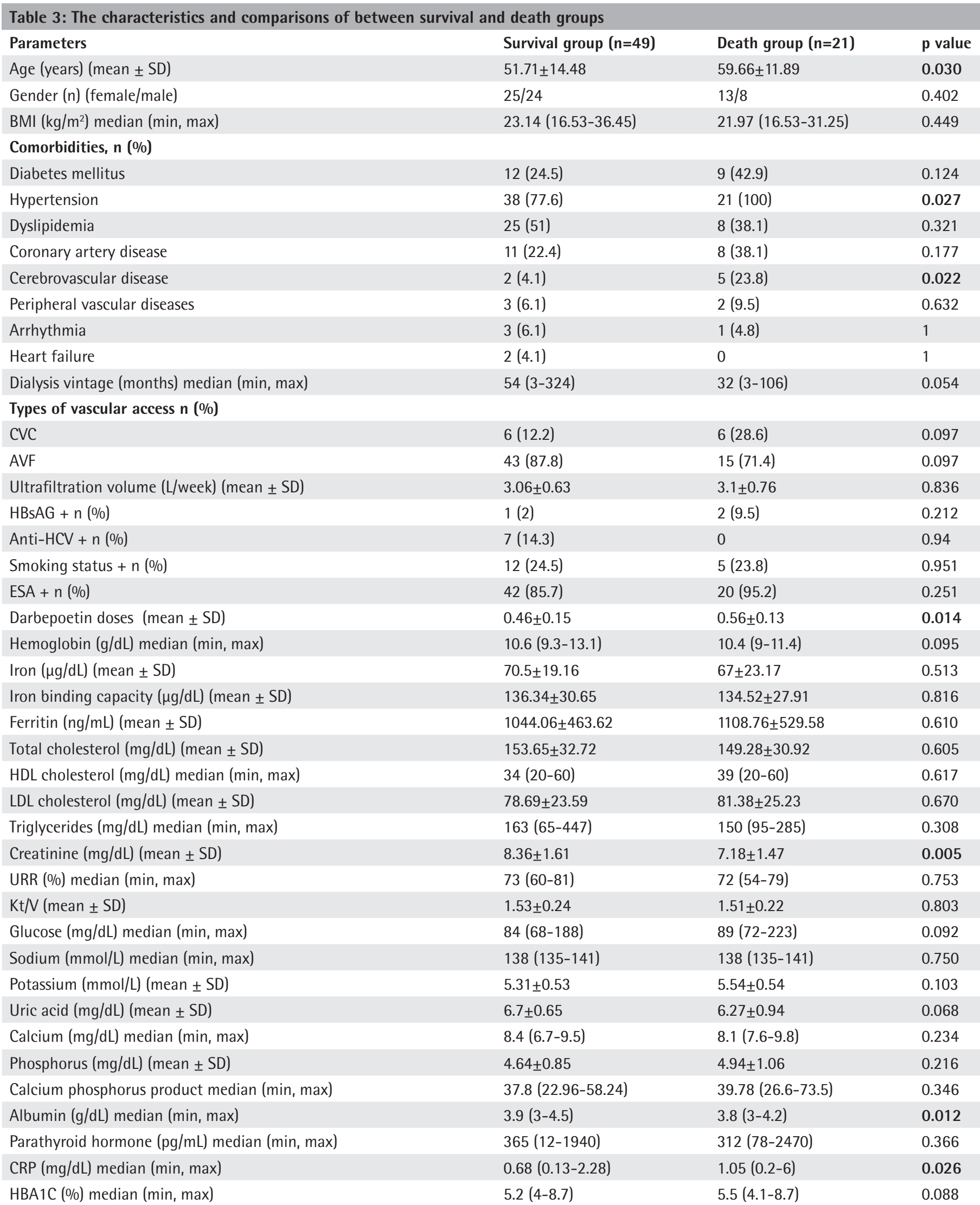

BMI: Body mass index, CVC: Central venous catheter, AVF: Arteriovenous fistula, ESA: Erythropoiesis stimulating agents, HDL: High-density lipoprotein, LDL: Low-density lipoprotein, URR: Urea reduction ratio, CRP: C-reactive protein, HBA1C: Glycated hemoglobin, HBsAG: Hepatitis B surface antigen, HCV: Hepatitis C virus, SD: Standard deviation, min: Minimum, max: Maximum, n: Number, K: Dialyzer clearance of urea, t: Dialysis time, V: Volume of distribution of urea 


\begin{tabular}{|c|c|c|c|c|}
\hline \multirow{2}{*}{ Parameters } & \multicolumn{2}{|c|}{ Univariate } & \multicolumn{2}{|c|}{ Multivariate } \\
\hline & OR $(95 \% \mathrm{CI})$ & $p$ value & OR $(95 \% \mathrm{Cl})$ & $\mathrm{p}$ value \\
\hline Diabetes mellitus & $2.312(0.784-6.824)$ & 0.129 & $3.583(1.003-12.808)$ & 0.05 \\
\hline Cerebrovascular disease & 7.344 (1.295-41.639) & 0.024 & $8.217(1.263-53.442)$ & 0.027 \\
\hline $\operatorname{CRP}(\uparrow)$ & 3.955 (1.327-11.794) & 0.014 & $4.340(1.306-14.416)$ & 0.017 \\
\hline
\end{tabular}

OR: Odds ratio, Cl: Confidence interval, CRP: C-reactive protein

European Renal Association-European Dialysis and Transplant Association Registry and showed that in dialysis patients mortality from non-cardiovascular disease was increased to the same extent as mortality from cardiovascular disease. Shastri et al. (20) reported the various causes of death in a large cohort of patients undergoing hemodialysis and showed that rates of sudden cardiac death, non-sudden cardiac death, and noncardiac death were $22 \%, 17 \%$, and $61 \%$, respectively. According to the Turkish Society of Nephrology's 2018 Registry Report, the most common cause of death in prevalent hemodialysis patients was cardiovascular (48\%), followed by cerebrovascular (14\%), malignancy (10.4\%), and infection (10\%) (21). In our study, during the follow-up period, 21 (28.4) patients died and the rates of death for cardiovascular events, infections, and gastrointestinal bleeding were $52.2 \%, 43 \%$, and $4.8 \%$, respectively. In our study, cardiovascular and cerebrovascular deaths were evaluated together as cardiovascular events. Cardiovascular deaths were the first among the causes of death. These findings were in accordance with the literature.

Inflammation plays an important role in the mortality in patients on chronic hemodialysis. CRP as a marker of inflammation can be used as a predictors of death. In a study on 280 hemodialysis patients, CRP was found to be strongly independent predictors of both overall death and cardiovascular death (22). This was in agreement with our study results. The relation between the type of vascular access and mortality has been reported in hemodialysis patients (23). The presence of a non-native vascular access device, including a CVC is the most common identifiable source of infection in patients on hemodialysis that contributes to increased mortality (24). In our study cohort, we found that the patients who died, as compared to living patients had a higher percentage of them used CVC for vascular access. However, it was not reaching statistically significance. This may be related to relatively small sample size.

The median hemoglobin level of our patients was $10.6 \mathrm{~g} / \mathrm{dL}$. Compared with the survival group, the death group had a lower hemoglobin levels and they required significantly higher ESA doses. Limited evidence suggests that an increased mortality may be due to high ESA doses. In one observational study of hemodialysis patients in the United States, in patients with persistently low hemoglobin levels $(<9.5 \mathrm{~g} / \mathrm{dL})$ and received larger ESA dose changes over an 11-month period had a higher mortality risk (25). In another study, lower erythropoietin responsiveness was a strong, independent predictor of mortality risk (26). However the association between higher ESA doses and mortality has not been shown in all studies. In one observational study, on average, epoetin dosages $>30,000$ unit/week were not confer additional harm or benefit in elderly hemodialysis patients (27).

Previous studies demonstrated that older age, previous atherosclerotic vascular disease, DM, higher levels of CRP and lower levels of albumin are associated with mortality in patients undergoing hemodialysis (28). Our results were in accordance with these studies. We found that most of hemodialysis patients were died secondary to atherosclerotic cardiovascular disease. Infection was the second leading cause of mortality in these patients. The death group patients were older, had higher comorbid conditions such as DM, HT, CAD, CVD and PAD, lower serum albumin and creatinine levels, and higher CRP levels when compared with the survival group. In univariate analysis, patients 65 years of age and older and serum albumin levels below $3.5 \mathrm{~g} / \mathrm{dL}$ were found associated with mortality, but in multivariate analysis did not show. We also found that DM, CVD, and higher CRP levels are three main predictors of mortality in MHD patients.

The assessment of nutritional status among hemodialysis patients is very important because of as a predictor of morbidity and mortality (29). However, there is no gold standart parameters in routine clinical practice for nutritional status assessment. Different markers such as serum albumin, creatinine, BMI, and lipid profile have been associated with mortality (30). Malnutrition associated with inflammation has been extensively studied in recent years and is considered a risk factor that increase the mortality in hemodialysis patients $(31,32)$. We evaluated the nutritional status by BMI, pre- 
dialysis serum albumin, creatinine, and lipid profile of patients. Although total cholesterol, triglycerides, and BMI were lower in the non-survival patients, there were not statistically significant among the groups. Only serum creatinine levels were lower in the died patients. With regard to hemodialysis efficacy, total $\mathrm{Kt} / \mathrm{V}$, ultrafiltration volume, and URR did not effect mortality in the present study. Regarding the mineral metabolism disorders serum calchium, phosphorus, parathyroid hormone, and calchium phosphorus product were not differ in both group of patients.

\section{Study Limitations}

Our study has some limitations. First, the number of patients included in this study and follow-up period were relatively limited. Second, as the baseline data were recorded at the start of the study, events occurring 2 years follow-up period may be explained by the course of the patients and not by the baseline status.

\section{Conclusion}

A careful evaluation are essential in MHD patients especially with DM, CVD, and high CRP levels. This provides to achieve timely the clinical goals and to improve survival in this group of patients.

\section{Ethics}

Ethics Committee Approval: Since this study is a retrospective observational cohort study conducted between January 2018 and January 2020, ethics committee approval was not obtained.

\section{Informed Consent: Retrospective study.}

Peer-review: Externally and internally peer-reviewed.

\section{Authorship Contributions}

Surgical and Medical Practices: Ş.E., Concept: S..E., Design: Ş.E., Data Collection or Processing:Ş.E., Analysis or Interpretation: Ş.E., F.K., Literature Search: Ş.E., Writing: Ş.E.

Conflict of Interest: No conflict of interest was declared by the authors.

Financial Disclosure: The authors declared that this study received no financial support.

\section{References}

1. Foley RN, Murray AM, Li S, et al. Chronic kidney disease and the risk for cardiovascular disease, renal replacement, and death in the United States Medicare population, 1998 to 1999. J Am Soc Nephrol. 2005;16:489-495.

2. Goodkin DA, Young EW, Kurokawa $K$, et al. Mortality among hemodialysis patients in Europe, Japan, and the United States: case mix effects. Am J Kidney Dis. 2004;44:16-21.

3. Foley RN, Parfrey PS, Sarnak MJ. Clinical epidemiology of cardiovascular disease in chronic renal disease. Am J Kidney Dis. 1998;32:S112-S119.
4. de Jager DJ, Grootendorst DC, Jager KJ, et al. Cardiovascular and noncardiovascular mortality among patients starting dialysis. JAMA. 2009;302:1782-1789.

5. Jager KJ, Lindholm B, Goldsmith D, et al. Cardiovascular and noncardiovascular mortality in dialysis patients: where is the link?. Kidney Int Suppl. 2011;1:21-23.

6. Collins AJ. Cardiovascular mortality in end-stage renal disease. Am J Med Sci. 2003;325:163-167.

7. Longenecker JC, Coresh J, Powe NR, et al. Traditional cardiovascular disease risk factors in dialysis patients compared with the general population: the CHOICE Study. J Am Soc Nephrol. 2002;13:1918-1927.

8. Keane WF, Collins AJ. Influence of co-morbidity on mortality and morbidity in patients treated with hemodialysis. Am J Kidney Dis. 1994;24:1010-1018.

9. Ikizler TA. Role of nutrition for cardiovascular risk reduction in chronic kidney disease patients. Adv Chronic Kidney Dis. 2004;11:162-171.

10. Carrero JJ, Stenvinkel P. Inflammation in end-stage renal disease--what have we learned in 10 years?. Semin Dial. 2010;23:498-509.

11. Costa $E$, Rocha $S$, Rocha-Pereira $P$, et al. Cross-talk between inflammation,coagulation/fibrinolysis and vascular access in hemodialysis patients. J Vasc Access. 2008;9:248-253.

12. Honda $H$, Qureshi $A R$, Heimbürger 0 , et al. Serum albumin, C-reactive protein, interleukin 6 , and fetuin a as predictors of malnutrition, cardiovascular disease, and mortality in patients with ESRD. Am J Kidney Dis. 2006;47:139-148.

13. Zhang $W$, He J, Zhang $F$, et al. Prognostic role of C-reactive protein and interleukin-6 in dialysis patients: a systematic review and meta-analysis. $J$ Nephrol. 2012;26:243-253.

14. Block GA, Klassen PS, Lazarus JM, et al. Mineral metabolism, mortality, and morbidity in maintenance hemodialysis. J Am Soc Nephrol. 2004;15:22082218.

15. American Diabetes Association. Classification and Diagnosis of Diabetes: Standards of Medical Care in Diabetes-2019. Diabetes Care. 2019;42(Suppl 1):S13-S28.

16. Williams B, Mancia G, Spiering W, et al. 2018 ESC/ESH Guidelines for the management of arterial hypertension: The Task Force for the management of arterial hypertension of the European Society of Cardiology and the European Society of Hypertension. J Hypertens. 2018;36:1953-2041.

17. Kidney Disease: Improving Global Outcomes (KDIGO) Lipid Working Group. KDIGO clinical practice guideline for lipid management in chronic kidney disease. Kidney Int. 2013; (Suppl. 3): 263-305.

18. Ferro $\mathrm{CJ}$, Mark PB, Kanbay $M$, et al. Lipid management in patients with chronic kidney disease. Nat Rev Nephrol. 2018;14:727-749.

19. Krediet RT, Boeschoten EW, Dekker FW. Are the high mortality rates in dialysis patients mainly due to cardiovascular causes?. Nephrol Dial Transplant. 2012;27:481-483.

20. Shastri S, Tangri N, Tighiouart $H$, et al. Predictors of sudden cardiac death: a competing risk approach in the hemodialysis study. Clin J Am Soc Nephrol. 2012;7:123-130.

21. National Nephrology. Dialysis and Transplantation Registry Report of Turkey; 2018. http://www.nefroloji.org.tr/folders/file/REGISTRY_2018.pdf

22. Zimmermann J, Herrlinger $S$, Pruy $A$, et al. Inflammation enhances cardiovascular risk and mortality in hemodialysis patients. Kidney Int. 1999;55:648-658.

23. Dhingra RK, Young EW, Hulbert-Shearon TE, et al. Type of vascular access and mortality in U.S. hemodialysis patients. Kidney Int. 2001;60:1443-1451.

24. Pastan S, Soucie JM, McClellan WM. Vascular access and increased risk of death among hemodialysis patients. Kidney Int. 2002;62:620-626.

25. Bradbury BD, Danese MD, Gleeson M, et al. Effect of Epoetin alfa dose changes on hemoglobin and mortality in hemodialysis patients with hemoglobin levels persistently below $11 \mathrm{~g} / \mathrm{dL}$. Clin J Am Soc Nephrol. 2009;4:630-637.

26. Kilpatrick RD, Critchlow CW, Fishbane $\mathrm{S}$, et al. Greater epoetin alfa responsiveness is associated with improved survival in hemodialysis patients. Clin J Am Soc Nephrol. 2008;3:1077-1083. 
27. Zhang $Y$, Thamer M, Cotter D, et al. Estimated effect of epoetin dosage on survival among elderly hemodialysis patients in the United States. Clin J Am Soc Nephrol. 2009;4:638-644.

28. Ma L, Zhao S. Risk factors for mortality in patients undergoing hemodialysis: A systematic review and meta-analysis. Int J Cardiol. 2017;238:151-158.

29. Qureshi AR, Alvestrand A, Divino-Filho JC, et al. Inflammation, malnutrition, and cardiac disease as predictors of mortality in hemodialysis patients. J Am Soc Nephrol. 2002;13(Suppl 1):S28-S36.
30. Segall L, Mardare NG, Ungureanu S, et al. Nutritional status evaluation and survival in haemodialysis patients in one centre from Romania. Nephrol Dial Transplant. 2009;24:2536-2540.

31. Fernández-Reyes MJ, Alvarez-Ude F, Sánchez $R$, et al. Inflammation and malnutrition as predictors of mortality in patients on hemodialysis. J Nephrol. 2002;15:136-143.

32. de Mutsert R, Grootendorst DC, Indemans F, et al. Association between serum albumin and mortality in dialysis patients is partly explained by inflammation, and not by malnutrition. J Ren Nutr. 2009;19:127-135. 